\title{
Implementation of Multidimensional Scaling (MDS) in Determining the Positioning of Rasa Dewa Juice: Strategy Micro Small Business (SME's) Product
}

\author{
Fatimah $^{1}$, Darna $^{2}$, Elisabeth Y.M. ${ }^{3}$ \\ \{fatimah@akuntansi.pnj.ac.id ${ }^{1}$, darna@ akuntansi.pnj.ac.id ${ }^{2}$, lisayansye@ yahoo.co.id ${ }^{3}$ \}
}

Politeknik Negeri Jakarta, Indonesia ${ }^{1,2,3}$

\begin{abstract}
Consumer perception of a product is important to be known by producers, so that producer can decide the right marketing communication. This study aims to analyze the positioning of consumer perceptions of Belimbing Dewa Juice products produced by small and micro enterprises (SMEs) in the city of Depok. The Multidimensional Scaling (MDS) method with the attributes of taste, packaging, promotion, and prestige is chosen to illustrate a map of consumer perceptions of Belimbing Dewa Juice. This method tries to compare Jus production of SMEs with three similar beverage products (Pulpy Orange, Floridina, and Coolant) produced by large producers. In this analysis, a purposive sampling approach is chosen by interviewing 100 consumers to be evaluated. MDS analysis results with attributes of taste, packaging, promotion, and prestige; shows that the position of Belimbing Dewa Juice is far apart from Coolant, Floridina and Pulpy Orange brand drinks with Euclidean distance (D) scales of $0.693 ; 1,117$ and 1,565. On the contrary, Coolant, Floridina, and Pulpy Orange are close to each other. This shows that packaged beverages from large producers compete with one another. Whereas the positioning of Belimbing Dewa Juice based on the attributes of taste, packaging, promotion, and prestige cannot be categorized as competitors of the three types of manufacturer's beverages.
\end{abstract}

Keywords: Multidimensional scaling, positioning, consumer perception

\section{Introduction}

Recent global economic development is experiencing intense competition that requires every producer to innovate the development and the improvement of its products' quality. According to Supriyadi [1], the quality of products is the main weakness of SME products which makes it difficult to compete with similar products produced by large companies. Beverage products which are made of local fruits are currently very diverse by offering different flavors, these conditions lead to high competition between one brand and another. In addition to being required to be able to compete through the quality of its products, fruitflavored beverage manufacturers are also required to be able to influence consumers through promotional activities that are vigorous in various print media, television media, billboards, and other promotional media.

Rasa Dewa juice is one of SMEs' brand who wants to be appointed as a superior product and a distinctive feature of Depok city because this product uses the raw material of starfruit which is considered as an "Icon" of Depok city. However, Rasa Dewa juice has not been widely known by the public, even by the people of Depok city themselves. The owners have 
only sold their products to consumers in their business environment through SME product exhibitions held by the Depok city government and bazaar activities held on colleges in Depok. Besides, access to the market is only done by entrusting this product at the SME'S Center and some souvenir shops on Margonda Depok street. This narrow scope of marketing results in a limited number of sales and production. Promotional activities are only carried out conventionally and rely on exhibitions and bazaars conducted by local governments and universities in Depok.

Targeted marketing by applying integrated formulations between segmentation, targeting and positioning (STP) can create successful SMEs. Prospective consumers who will be served by SMEs must be ensured their characteristics, while the targeted segment must be able to meet the company's targets and strategic positioning programs that make the marketed products get a positive place in the minds of consumers. According to Astina [2], the STP design can maintain the competitiveness of a company in facing a lot of competition. While research from Afrizal [3] concluded that sales volume experienced a significant increase after the company segmented the market. Market segmentation has a significant effect on sales volume and the segmentation program can be said to run effectively, but market segmentation alone is not enough to increase sales. Products marketed must also be communicated to prospective customers. The right marketing communication will make the product have a positive position in the minds of consumers. This can be done through a positioning strategy.

According to research by Danibrata [4] on the positioning of Extra Joss products, the company positioned this product in the minds of consumers that this beverage is a health beverage product for young, fit and strong people. The producers choose sachets as the packaging instead of bottles as an image of the product "What is the bottle for, this is the Priory of Health Drinks."

Making a consumer perception map can produce information as a basis for making a product positioning strategy. Creating the right positioning strategy for a product requires the marketer to clearly communicate all product attributes, taste, price, packaging, nutritional content and promotion and pride in the product. The visual presentation of perception maps in the form of images is an advantage because it greatly facilitates marketers in reading consumer perceptions. The method used in analyzing consumer perceptions is to use product attributes in describing positioning and also depicting an object one with another object using multidimensional scaling analyzes (MDS).

This study aims to look at consumer perception maps of Rasa Dewa juice as a product of small and micro enterprises (SME's) in Depok city using the MDS method. So that the final results of this study can answer the author's curiosity about an effective positioning strategy that must be applied by micro-businesses of the Rasa Dewa juice to be able to grow up to a higher class.

\section{Literature Review}

Factor analysis is used to analyze the interaction between variables. All variables have the same status, there are no independent variables that predict the independent variables as found in the dependent method. Using factor analysis will be able to know the dimensions that underlie a number of attributes. The use of this technique will make the attributes of a number of brands can be analyzed. The scores obtained and possessed can be used to create your own perception map. Factor analysis does not provide output in the form of perception maps but can provide data that is the score of factors that can later be used for these purposes [5]. 
The perceptual map describes the position of a product, brand product line, or a company that deals with its competitors. It can also describe several sizes, but the most common are only those two sizes. Perceptual map definition is; "A visualization technique that indicates how customer perceive competing brands are in terms of various criteria" [6]. The perceptual map is a graphical technique which is used by marketers who aim to provide a view of the perception of consumers or potential consumers. Usually positioning a product, the variety of products, brands or companies displayed in competition.

Positioning strategy is very important in marketing a product because it affirms the brand's position of the product among other brands. This strategy serves to distinguish itself from competitors in the minds of consumers or commonly referred to as "minds of consumers". One way to measure consumer perception is by using a perceptual map. Although it is difficult to measure the perception because of its abstractness, it still can be compared. The object that is observed in this case can be the name of the product, company or brand. Perception map is a technique that can help marketers or producers differentiate products seen by consumers in competition with both direct competitors and indirect competitors. Perception mapping shows the position of goods or products chosen by consumers according to what they taste. Each choice occupies a special place in the minds of consumers. Product positioning strategies in marketing management have emerged and many companies are currently conducting studies on this strategy [7].

Sutojo [8] defines positioning as a step to position yourself appropriately in each market segment, done by comparing the strengths and weaknesses of companies with competitors operating in the same market segment. There are at least seven approaches that are used to do positioning, namely [9]; 1) positioning based on attributes, characteristics or benefits for the customer (attribute positioning). The selection of attributes that will be used as the basis for positioning are: a) importance; b) distinctiveness; c) superiority; d) communicability; e) preemptive; f) affordability; g) profitability. 2) positioning based on price and quality positioning; 3) positioning based on aspects of use or application (use/application positioning); 4) positioning based on the product user (user positioning); 5) positioning based on certain product classes (product class positioning); 6) positioning regarding competitors (competitor positioning); 7) positioning based on benefits (benefit positioning).

The main objectives of positioning analysis [9] are: a) to place or position products in the market, so that the product is separated or different from competing brands; b) to position the product so that it can convey several key things to customers, namely for what the product is and how it receives evaluation from customers.

When going to position a product into the minds of consumers, a marketer must identify what variables or attributes are considered important from a product by consumers. After that, the marketer can do a positioning study to determine the target market perceptions. As an example of a perception map of motorcycle purchases where consumers consider important attributes are purchase prices, resale prices, fuel used, spare parts availability, brand reputation, engine durability, speed, safety, models and colors. Positioning research results can be described visually in the form of perception maps that place a number of brands based on these important attributes [10].

Marketing communication dominates business activities in the era of modern marketing and is closely related to the character and behavior of the community. A marketing communications planner is to identify different market groups. The market identification process is carried out by conducting strategic mapping containing 3 main elements, namely segmentation, target market, and positioning. Positioning is an attempt to design an offer and an image of a company or a product and the image of a product. According to Kotler [11], 
positioning is the placement of products in the form of meaning that controls the area of certain competitive positions that are in the minds of consumers as the target market. For example, the brands of Audi, BMW, and MERCEDES are accepted in the minds of consumers as offering different products based on value, quality, and meaning or the image of each for the luxury car category.

Research using a consumer perception map of a habitable housing environment produces consumers who want housing that has advantages in the attributes of public facilities, architectural design, and social facilities. From these results, the developer must cooperate with various agencies that are able to provide public facilities, because these facilities are the most needed by consumers [12]. In other studies that use perceptual maps of several mobile brands it turns out that each brand is viewed differently by consumers, this can be seen from each brand in each different quadrant [13].

In this research concerning segmentation, targeting and positioning strategy, it turns out that Kecap Blekok company has a segment of the lower middle class and the target market is only a single market segment and the company positions the company even though the middle to lower class is high-quality products. The pricing strategy uses the cost-plus pricing method and is not affected by the selling price of competitor products and discriminating the selling price [14]. In other studies related to health supplement products, namely Extra Joss, the target market for this product is a group of people who need additional energy that has high vitality, hard work. This product is described as a product that makes people become fresh, young and strong. The company positioned its product with the image of "This is the culprit, for what is the bottle" which was then changed again to "The Primer of Health Drinks". The "Primer" word is the positioning of this product [4].

\section{Methodology}

The method used in this research is a descriptive method and quantitative analytical method. The descriptive method focuses on disclosing factual facts as they are from all the problems faced by micro and small entrepreneurs in the city of Depok. Facts disclosure is carried out through stages of activities which include data collection using instruments in the form of questionnaires, tabulating data, analyzing, interpreting and making conclusions.

The population in this study are all consumers of Rasa Dewa Juice which are spread throughout Depok city. Because the research population is large and spread, it will be effective and efficient if the research does not use all members of the population as objects of research. Therefore in this study sample data was used by selecting a purposive non-random sampling technique, where the number of samples was determined by researchers as many as 100 consumers from all members of the population.

The quantitative analytical method uses inferential statistics which is analyzing the sample data. The results from the sample analysis are used to generalize the state of the population. The data analysis technique used is multidimensional scaling (MDS) analysis with SPSS software version 20. MDS is a statistical technique for technical interdependent group techniques that can map consumer perceptions visually.

Besides, the technique used in this MDS analysis are as follows: 1) primary data input obtained through interviews; 2) conducting an aggregate MDS analysis that combines all product attributes analyzed; 3 ) test the results with the Stress and Goodness of Fit numbers and 4) interpret the perception map; 5) conducting preference analysis and 6) making 
positioning strategies for SME'S Rasa Dewa products to be able to survive and even compete with other similar products.

The formula used to test the model and measure geometric distances (Euclidean distance) is as follows:

$$
\text { Stress }=\sqrt{\frac{\left(d_{i j}-\hat{d}_{i j}\right)^{2}}{\left(d_{i j}-\bar{d}\right)^{2}}}
$$

as:

$\bar{d}=$ average distance on the map

$\hat{d}_{i j}=$ derived distance or data similarity (computer data)

$d_{i j}=$ distance data provided by the respondent

$$
\mathrm{D}=\sqrt{\left(\mathrm{x}_{\mathrm{i}}-\mathrm{x}_{\mathrm{i}-1}\right)^{2}+\left(\mathrm{y}_{\mathrm{i}}-\mathrm{y}_{\mathrm{i}-1}\right)^{2}}
$$

as:

$$
\begin{aligned}
& \mathrm{D}=\text { geometric distance (Euclidean distance) } \\
& \mathrm{x}_{\mathrm{i}}=\mathrm{x} \text { coordinates to } \mathrm{i} \\
& \mathrm{y}_{\mathrm{i}}=\mathrm{y} \text { coordinates to } \mathrm{i}
\end{aligned}
$$

\section{Result and Discussion}

The results of aggregate positioning analysis using the attributes of taste, packaging, promotion, and prestige between Rasa Dewa Juice as SME's products compared to similar beverage products from large companies namely Pulpy Orange, Floridina and Coolant obtained the following test results and perception maps:

Table 1. Stress and Fit Measure Aggregate test

$$
\text { STRESS AND FIT MEASURE }
$$

\begin{tabular}{ccc}
\hline Attribute & Stress & Goodness of fit \\
\hline Total & 0.00000 & Perfect \\
\hline
\end{tabular}

Table 2. Distances (Euclidean Geometric Distance)

Dimensionality: 1

\begin{tabular}{lrccc}
\hline & Coolant & Floridina & Jusrsdewa & Pulpy \\
\hline Coolant & .000 & & & \\
Floridina & .424 & .000 & & \\
Jusrsdewa & .693 & 1.117 & .000 & \\
Pulpy & .872 & .449 & 1.565 & .000 \\
\hline
\end{tabular}

As seen from the geometric distance (Euclidean distance) in table 2, the product of Rasa Dewa juice belongs to SME'S closest to Coolant $(0.693)$, then Floridina $(1,117)$ and the 
furthest with Pulpy Orange $(1,565)$. The greater the Euclidean distance number indicates that the product is increasingly not similar.

From Figure 1 below shows that the position of the Coolant, Floridina, and Pulpy Orange products have an adjacent position. This means that the three beverage brands can be said to compete with each other. Whereas for Depok's Rasa Dewa juice products, Depok city is far apart from the three, this means that Rasa Dewa juice is not a competitor of the three manufacturer's beverage products.

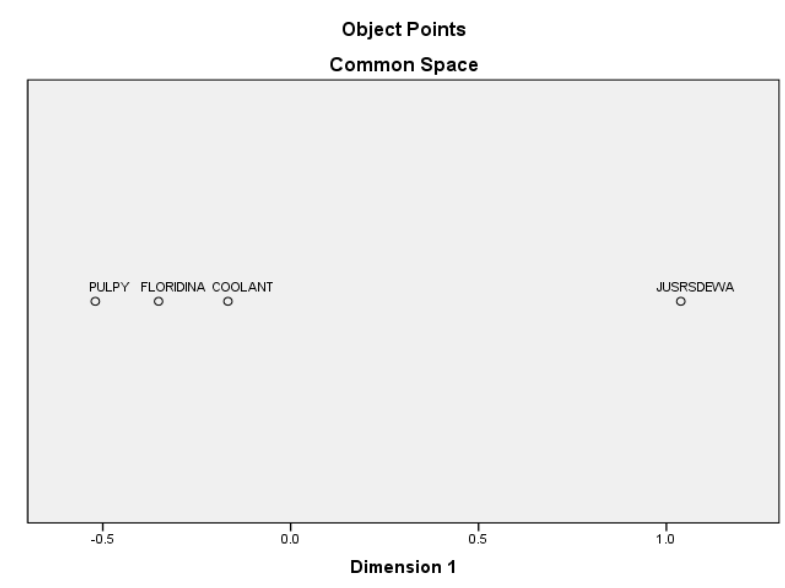

Figure 1. Perceptual map for total attributes (aggregate)

The following are the results of the Rasa Dewa juice product positioning test based on taste, packaging, promotion and prestige attributes compared to the other three products for each attribute.

Table 3. Stress and Fit Measure test per attribute

STRESS AND FIT MEASURE

\begin{tabular}{lcc}
\hline \multicolumn{1}{c}{ Attribute } & Stress & Goodness offit \\
\hline Taste & 0.00028 & Perfect \\
Packaging & 0.00029 & Perfect \\
Promotion & 0.00031 & Perfect \\
Prestige & 0.11348 & Fair \\
\hline
\end{tabular}

The results of the stress test and fit measures for the attributes of taste, the attributes of each packaging and promotion produce a very good model with a level of goodness of fit Perfect, only prestige attributes that produce a model with a fair level of goodness of fit.

Based on the flavor attribute the position of the Coolant, Floridina, and Pulpy Orange has an adjacent position. This means that the three brands of beverage based on taste can be considered to have similarities. The taste of Rasa Dewa juice, according to consumer perception, does not have the same taste compared to Coolant, Floridina, and Pulpy Orange. This result is supported by the Euclidean distance, where the distance of Belimbing Dewa juice to Floridina 1,371, to Coolant 1,413 and to Pulpy Orange is 1,453 .

Based on packaging attribute, the position of the Coolant, Floridina, and Pulpy Orange has an adjacent position. This means that the three beverage brands based on their packaging can be considered to have similarities. Where as for Depok's Rasa Dewa juice is far apart from 
the three types of beverages, this means that the Rasa Dewa juice, according to consumer's perception has no similarity compared to Coolant, Floridina, and Pulpy Orange. This result is supported by the Euclidean distance, where the Rasa Dewa juice distance to Coolant 1.370, to Pulpy Orange 1.412 and to Floridina is 1.454 .

Based on promotional attributes that the position of Coolant, Floridina and Pulpy Orange products have a close position. This means that the three brands of beverage based on the promotion can be said to have similarities. Whereas for the Rasa Dewa product owned by SME's of Depok city, its position is far from the three types of beverage, it means that the Rasa Dewa brand juice has not been widely known by the public. This result was confirmed by the Euclidean distance, where the Rasa Dewa juice distance to Coolant 1.369, to Floridina 1.412 and to Pulpy Orange was 1.455 .

Based on prestige attributes, the position of Coolant, Floridina, and Pulpy Orange has a close position. This means that the three brands of beverage based on prestige can be considered to have similarities. Whereas the position Rasa Dewa juice product is far from the three types of beverage. This means that the Rasa Dewa brand juice has not been widely consumed by the community. This result was confirmed by the Euclidean distance, where the Rasa Dewa juice distance to Coolant 0.693, to Floridina 1.117 and to Pulpy orange is 1.565 .

The superiority of Rasa Dewa juice is a kind of beverage produced without preservatives so that from the health side it is relatively safe. In addition to having a sweet taste, star fruit turned out to have a number of benefits for the body including containing vitamins $\mathrm{A}$ and $\mathrm{C}$ which function as antioxidants that can fight free radicals and contain calcium, potassium, phosphorus, and iron. Another feature of starfruit also has good fiber content which helps smooth the digestive process. Its high potassium content and low sodium are very helpful in reducing high blood pressure levels. Besides that, this fruit can help reduce levels of bad cholesterol in our body so that it can avoid dangerous diseases.

The consumer perception map of the Rasa Dewa juice drink with all its product attributes in the form of taste, packaging, promotion, and prestige is illustrated that this drink is not yet a competitor of the type of Coolant, Floridina and Pulpy Orange (figure 1). This is something that is natural because all this time the Rasa Dewa juice has not been widely known by consumers, so consumers are still unfamiliar with the taste of the product. From the packaging aspect, the Rasa Dewa juice drink, the SME production is still far below the quality compared to the three types of packaging products produced by large companies. The promotion conducted by SMEs is word-of-mouth advertising with a wide range of promotions that are limited only in Depok city. This is what makes the Rasa Dewa juice unable to compete with similar products that already have a brand that is known to the public nationally. Thus positioning the brand Rasa Dewa juice in the hearts of consumers is still much lower than other types of freshness drinks.

The positioning of beverage products Rasa Dewa Juice is needed as a marketing strategy so that its market share can be improved and can compete with products from large industries. In the perception map, it has been described that this product has a different place in the minds of consumers than other beverage products. Therefore, producers need to build a juice flavor product brand in the minds or minds of consumers at the highest level, thus forming consumer confidence as follows: "If it is not Rasa Dewa Juice, it is better not to consume Juice". According to research from [15], based on several variables that are used as the distinguishing basis between Jambi batik and Javanese batik, which are product variables, service, personnel, distribution channels, and product image, it turns out that consumers do not have different perceptions between the two products. Then it becomes difficult for Jambi batik to the position as a different product with Javanese batik. While research from Nasution [16] turns 
out that consumer perceptions in determining their choices are determined by several variables, which are the system in the company, facilities owned by the company, professionalism of employees, quality of service and assurance of the product.

The opposite thing happened to SME's Rasa Dewa products. This product is perceived differently by consumers with other beverage groups, such as the Pulpy Orange brand, Floridina brand and Coolant brand. Based on a study by Yohana [17], it turns out that the quality of SME products, prices and services greatly influences consumers' buying interest. While the research of Melwinda[18] who conducted research on consumer perceptions of several Laptop products showed that based on the overall attributes of design, operating system, set features, specifications, processor, battery life, product quality turned out to be the best consumer perception of other brands.

Another research from Chowdhury, Partha Prasad [19] said that to do positioning, a company needs all relevant information related to competition and markets to place their brands in the mindset of the target customers, by creating values that offer a difference from competitors. The positioning will guide or direct marketing strategies; will help distinguish the brand from its position on the market; help companies/firms to secure financial returns (financial returns) from the target market. Whereas Karadeniz, Mustafa [7] research companies that develop their positioning strategies must determine the attributes and image of the competitor accurately. Then, they must design positioning strategies for the products they produce or offer. The main purpose of doing this is to know products that are not produced by competitors, but are desired by consumers, and apply positioning strategies in this way:

Some strategies that can be done by the Dewa Rasa SME so that this product can be embedded in the minds of consumers are,

1. Product Attributes: at the moment, in the Indonesian market, there is a lot of beverage products circulating both based on fruits and soft drinks. Each has a different position. There are some products which are perceived as a beverage to accompany breakfast, there are some which are considered as evening drinks or special drinks to accompany a trip or to refresh body after exercising. Jus Rasa Dewa must look for a different position with competitors. SME's must seek excellence from their products that can be highlighted and differentiate with competitors. Because it is made from star fruit which is used as a fruit icon of Depok city, Rasa Dewa juice can position its products in the minds of consumers as a typical drink in Depok. For that, the manufacturer of Rasa Dewa SME's brand can make marketing communication by emphasizing "If you are coming to Depok, make sure to taste the Rasa Dewa juice".

2. Product Benefits: product benefits are associated with certain uses. People are convinced that star fruit is very healthy. In addition to reducing hypertension, starfruit is also useful as a cholesterol-lowering food. Manufacturers must communicate to consumers that hypertension and high cholesterol are not diseases that can only attack at the old age but can affect at anytime no matter how old the age of someone. It is expected that consumers look for Rasa Dewa juice drink whenever they do not know the time, morning, noon or night after consuming heavy food. Manufacturers can instill in the minds of consumers that "want to be healthy do not forget to drink Rasa Dewa juice".

3. According to the User: many products when marketed are associated and positioned with the lifestyle adopted by the user. Rasa Dewa Juice can position the product with a user who has a healthy lifestyle. This strategy can be applied considering that more and more people are choosing a healthy life by avoiding soft drinks that are high in sugar. Besides, the Rasa Dewa juice is also a solution for them to stay healthy without 
without having to lose the favor of a sweet and delicious drink. Communicate to consumers that "healthy living is by living with a healthy drink". In this case, the healthy drink is Rasa Dewa juice.

4. According to Competitors: the Rasa Rasa juice competitor in this study is Pulpy Orange and Floridina can be considered as large business production. This product emphasizes that their beverage product is very special. For example, the Pulpy Orange contains the grains of orange so that drinking Pulpy Orange seems to eat genuine citrus fruit. Jus Rasa Dewa can highlight SME products by embeding in the minds of consumers that if consuming SME'S Rasa Dewa products means helping to increase domestic production and strengthen people's economy. Rasa Dewa SME can also instill in the minds of consumers that this small business product certainly does not contain preservatives so that the freshness is maintained. Embed in the minds of consumers, a sense of attachment for SME products, such as attachment for Indonesia means to have the attachment with small business products.

5. Price: keep in mind the consumer that the price for the Rasa Dewa product is very reasonable. Health is the most important thing in life. Consumers should be aware that it is far cheaper to maintain health than cure. Therefore the price of the Rasa Dewa juice is very low when compared to treating diseases that arise from the lifestyle of people who do not like to consume fruit, especially star fruit.

\section{Conclusion}

Research to find out the positioning of a product in consumer's hearts needs to be done by every producer, especially food or beverage products that have a variety of types, which causes very tight competition, not least for SME-made products. By knowing the positioning, the juice rasa dewa can use it as the basis of the marketing strategy so that its market share can be improved and can even compete with similar products from large industries. In the MDS analysis here, a perception map of starfruit juice has been described that this product has a different place in the minds of consumers than other beverage products. Therefore, producers need to build "RASA DEWA" juice product brands in the minds or minds of consumers at the highest level, thus forming consumer confidence that consuming rasa dewa juice can improve body fitness.

This study only analyzes the attributes that are considered most important to consumers that give an impression of a beverage product, namely the attributes of taste, packaging, promotion and prestige. MDS analysis should include many attributes to be used in analyzing consumer perceptions of a product. This is the limitation in the study, however, the total consumer perception map of "Rasa Dewa" Starfruit Juice cannot be compared with other drinks produced by large companies.

In this study, only a consumer perception map of "Rasa Dewa" starfruit juice produced from SMEs compared to other beverage products that are produced by a large company. Therefore, the strategy that must be applied to position starfruit juice in the hearts of consumers will be different from other drinks produced by large companies. For further research that should be done is the evaluation of marketing communications that have not been carried out by the manufacturer of starfruit Juice "Rasa Dewa". 


\section{References}

[1] Supriyadi, Dedy, 2010, Meningkatkan Daya Saing Produk SME'S Melalui Perbaikan Mutu Produk, Jurnal Tri Darma Febuari (2010).

[2] Astina, Sylvia Tri. Analisis Segmentation, Targeting, dan Positioning dalam Rangka Meningkatkan Daya Saing Melalui Strategi Pemasaran di Toko Pia Cap Mangkok Cabang Semeru, Jurnal Administrasi Bisnis (JAB) Vol 39 No 2 Oktober 2016 hal 57 - 65 (2016).

[3] Aprizal, Hendry (2012), Analisis Efektivitas Segmentasi Pasar Terhadap Peningkatan Volume Penjualan Pada PT SEMEN TONASA di Pangkep, Skripsi: Jurusan Manajemen Fakultas Ekonomi dan Bisnis Universitas Hasanudin.

[4] Danibrata, A. Strategi Segmenting, Targeting, Positioning Produk Extra Joss. Jurnal Trisakti School of Management vol 1 No 1, 9 - 14 (2009).

[5] Simamora, B. Analisis Multivariat Pemasaran. Jakarta: Gramedia Pustaka Utama (2005).”

[6] Duncan, Tom. Principles of advertising and imc(2nd ed). McGraw-Hill p. 7 (2005).

[7] Karadeniz, Mustafa. Product Positioning Strategy in Marketing Management. Journal of Naval Science and Engineering, Vol. 5 (2), 98-110 (2009).

[8] Sutojo, Siswanto. Manajemen Pemasaran Edisi Kedua. Jakarta: PT Damar Mulia Pustaka (2009).

[9] Tjiptono, Fandy. Strategi Pemasaran. Yogyakarta: Andi (2008).”

[10] Chandra, F. T. Pemasaran Strategik. yogyakarta: Andi (2012).

[11] Kotler, Philip dan Armstrong. Principles of Marketing, IE. Prentice-Hall, New Jersey (2008).”

[12] Anastasia, N. Peta Persepsi Konsumen Terhadap Atribut Rumah Tangga di Surabaya. Jurnal Manajemen dan Kewirausahaan Vol 15 No 2, 141 - 152 (2013).

[13] Julio, D. Pemetaan Persepsi Merek HandPhone di Kalangan Mahasiswa. Jurnal Fekon vol 2 No $1,1-14$ (2015).

[14] Hari Wijaya, H. S. Strategi Segmenting, Targeting, Positioning serta Strategi Harga pada Perusahaan Kecap Blekok . AJIE-Asian Journal of Innovation and Enterpreneurship Vol 01 No 03, $175-189$ (2016)

[15] Octavia, Ade. Strategi Positioning Produk Batik Jambi, Jurnal Manajemen Terapan dan Keuangan ISSN 22528636 Vol 2 No 3 Https://on line-journal.unja.ac.id/index.pi (2013).

[16] Nasution, Reza dan Aprianingsih, Atik. Peta persepsi Multivariat Dari Penyedia Jasa Tranportasi Menuju Bandara Soekarno Hatta di Kota Bandung Jurnal Manajemen Teknologi Volume 7 No 2 (2008).

[17] Yohana F. Chaya. Jurnal Manajemen dan Kewirausahaan Vol 14, No 2, September 2012, 164 172 (2012).

[18] Melwinda, Wiwik. Jurnal Bisnis dan Iptek Sekolah Tinggi Ilmu Ekonomi Pasundan Bandung Vol 10 No 1 April 2017 hal 51 - 64 issn 2502-1559 (2017).

[19] Chowdhury, Partha Prasad. Key Strategies and Issues of Positioning: A Review of Past Studies. American Academic \& Scholarly Research Journal, Vol. 5 (1), 55 - 66 (2013). 